\title{
Combined Radiation and Hormonal Therapy for Squamous Cell Carcinoma of the Prostate: A Case Report and Review of the Literature
}

\section{Prostatın Skuamöz Hücre Karsinomu Tedavisinde Kombine Hormonoterapi ve Radyoterapi: Olgu Sunumu Eşliğinde Literatür Değerlendirmesi}

\author{
Muhammet Fatih Kılınç1, Tolga Karakan1, Elif Özer2, Demirhan Orsan Demir1, Yasin Aydoğmuş3, \\ Ömer Gökhan Doluoğlu1
}

\author{
1'Ankara Training and Research Hospital, Clinic of Urology, Ankara, Turkey \\ 2Ankara Training and Research Hospital, Clinic of Pathology, Ankara, Turkey \\ 3Etimesgut Military Hospital, Clinic of Urology, Ankara, Turkey
}

\begin{abstract}
Squamous cell carcinoma (SCC) of the prostate is a rare entity, with a prevalence of $0.6-1 \%$ among all prostatic carcinomas. Prostatic SCC has a poor prognosis. Although there are a number of treatment modalities, none of them have promised a long-term survival. Herein, we report a case of SCC coexisting with adenocarcinoma of the prostate treated with a combination of hormonal therapy, leuprolide acetate, and radiotherapy. Twenty-four months after treatment, the patient did not progress into metastatic or end-stage disease with the combination treatment modality. The treatment modalities for SCC are still limited. Comparisons of surgery and radiotherapy, and chemotherapy and hormonal therapy showed that they were all ineffective. Combined radiotherapy and hormone therapy may hold promise for longer survival.
\end{abstract}

Keywords

Hormonal therapy, squamous cell carcinoma of prostate, radiotherapy

\section{ÖZ}

Prostatın skuamöz hücreli karsinom (SHK) tüm prostat karsinom arasında \%0,6-1 prevalansı ile nadir görülen bir durumdur. SHK kötü prognoza sahiptir. Çeşitli tedavi modaliteleri olmasına rağmen, bunların hiçbiri uzun süreli yaşam vaat etmezler. Bu yazıda hormon tedavisi ve radyoterapi kombinasyonu ile tedavi olan adenokarsinom birlikteliği ile olan prostatik SHK olgusu sunuldu. Yirmi dört ay tedavi sonrası, hastada kombinasyon tedavi yöntemi ile metastatik ya da son evre hastalık haline ilerleme olmadı. SHK için tedavi yöntemleri hala sınırlı olmasına rağmen kombine radyo ve hormonoterapi bu hastalık için uzun yaşam süresini vaat edebilir.

\section{Anahtar Kelimeler}

Hormonoterapi, prostatın skuamöz hücre karsinomu, radyoterapi

\section{Introduction}

It has been well-known that the majority of prostate cancers are adenocarcinomas (up to 95\%), and pure squamous cell carcinoma (SCC) of the prostate is an extremely rare entity with an incidence of 0.6-1\% among all prostatic carcinomas (1). One third of patients with SCC present with normal prostate-specific antigen (PSA) values, and digital rectal examination (DRE) may be more predictive for those patients (2). Prostate SCC has a poor prognosis, and the median survival is about 14 months after diagnosis (3). Approximately $50 \%$ of cases present with pure SCC, and SCC coexists with adenocarcinoma in $25-50 \%$ of cases (4). Although a number of treatment modalities including radical surgical approaches, chemotherapy, hormone and radiation therapy have been used, however, none of them have promised a long-term survival. In this paper, we report a patient who was diagnosed with prostatic SCC coexisting with adenocarcinoma and treated with hormonal therapy combined with radiation therapy.

\section{Case Presentation}

A 69-year-old male patient was admitted to our urology outpatient clinic with a 6-month history of lower urinary tract symptoms (January 
2011). His serum PSA level was $0.43 \mathrm{ng} / \mathrm{ml}$. A transrectal ultrasoundguided prostate biopsy had been performed previously due to stony hard DRE, and the histopathological examination revealed focal squamous metaplasia areas with dysplastic differentiation, without any adenocarcinomatous component, in two of 12 cores. The patient had been treated with an alpha blocker. Two years later (January 2013), the patient complained of voiding difficulty, dysuria, and macroscopic hematuria. A computed tomography (CT) was obtained due to a stony hard and enlarged prostate on DRE, and a normal PSA value $(0.65$ $\mathrm{ng} / \mathrm{ml}$ ). CT showed an irregularly enlarged prostate, a prostatic mass extending into the bladder neck, bilateral moderate hydronephrosis, and no lymph node enlargement (Figure 1A). Bone scintigraphy was normal. Serum urea and creatinine levels were high $(48 \mathrm{mg} / \mathrm{dl}$ and $1.73 \mathrm{mg} / \mathrm{dl}$, respectively). After obtaining written informed consent from the patient, transurethral resection of the prostate, cystoscopy and transureteral resection of the suspicious areas of the bladder were performed in one session. Nephrostomy tubes were placed bilaterally. Biopsy revealed moderately differentiated adenocarcinoma with a Gleason score of $5+4$, and SCC of the prostate. It was also reported that SCC component of prostatic adenocarcinoma infiltrated epithelial lining of the bladder (Figure 2).

The patient was diagnosed with local-invasive disease, and has been managed with radiotherapy and hormonal therapy with leuprolide acetate since February 2013. He received leuprolide acetate $22.5 \mathrm{mg}$ followed by radiotherapy gray (Gy) 56 Gy to the pelvis, and 10 Gy to the prostatic area. He tolerated the treatment well, and no acute toxicities were seen. Bilateral nephrostomies were removed 6 months after surgery.

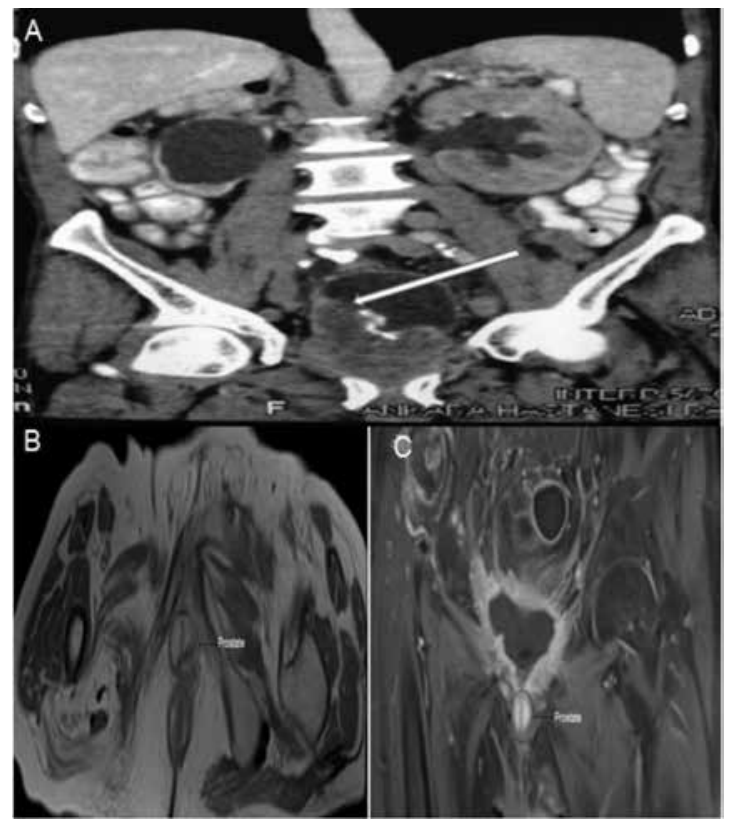

Figure 1. A) Sagittal computerized tomography section demonstrating extension of mass to soft tissues, to the base of bladder (arrow), and moderate hydronephrosis on the left and severe hydronephrosis on the right sides. B) Axial T1-weighted spin echo magnetic resonance image demonstrating reduced volume of the prostate after combination of radiotherapy and hormonal therapy. C) Coronal T1-weighted turbo-spin echo fat-sat magnetic resonance image of the prostate, 24 months after combination therapy. Note the lack of infiltration in bladder soft tissues
He complained of infrequent voiding difficulty and recurrent macroscopic hematuria at postoperative $2^{\text {nd }}$ year follow-up visit. Bilateral severe hydroureteronephrosis has been persisting and his serum urea and creatinine levels did not increase $(48 \mathrm{mg} / \mathrm{dl}$ and 2.3 $\mathrm{mg} / \mathrm{dl}$, respectively), therefore, he did not require dialysis. No bone metastasis was detected on control bone scintigrapy. Our patient's local-invasive disease has not progressed to metastatic or end-stage disease after combination treatment with radiation and hormonal therapy (Figure 1B, C).

\section{Discussion}

SCC of the prostate usually presents with outlet obstruction symptoms, similar to other prostatic diseases. Three-tiered classification of prostate cancer includes well-, moderately- and poorly-differentiated categories. The Gleason grading may be used for glandular component, but not for squamous component (2). Primary SCC of the prostate is an aggressive neoplasm found in less than $1 \%$ of men worldwide. The histopathological characteristics of prostatic SCC were first described by Mott (5). Those criteria are important to differentiate prostate SCC from non-neoplastic squamous metaplasia (secondary to infarct, acute/chronic prostatitis, granulomatous prostatitis due to Bacillus Calmette-Guerin, estrogen therapy, or radiation therapy) (3). Clinical features pointing towards the diagnosis of prostate SCC include a variable consistency of prostate on DRE; prostate is not always hard on palpation. Different from primary adenocarcinoma of the prostate, serum PSA and acid phosphatase levels are usually within the normal ranges, even in the presence of metastasis. In most of the cases, degree of histological differentiation is moderate. Squamous

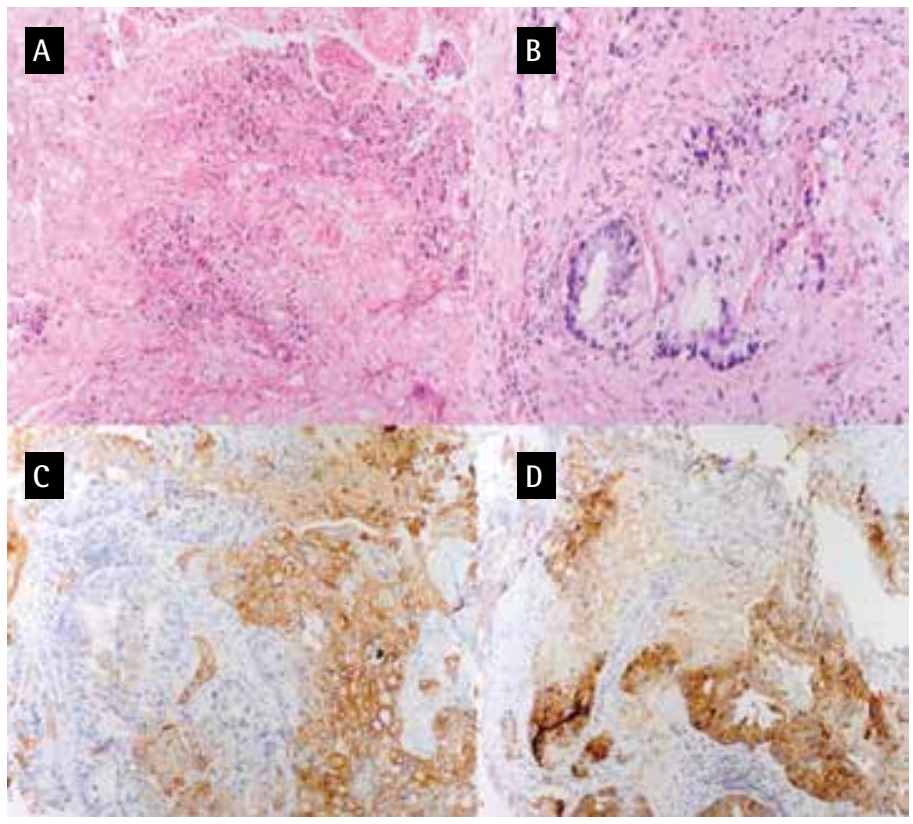

Figure 2. Sections stained with hematoxylin and eosin show only sheets of squamous cell carcinoma, A) original magnification $x 100$ ) with adjacent focal areas of adenocarcinoma B) original magnification $\times 200$ ). Immunohistochemistry was positive for high molecular weight cytokeratin C) original magnification $\times 100$ ) and prostate-specific antigen D) original magnification $\times 100$ ) in squamous cell carcinoma, however adenocarcinoma cells were negative for high molecular weight cytokeratin and prostate-specific antigen $(C, D)$ 
component is together with adenocarcinoma in 5-95\% of cases. The morphology does not have any prognostic significance when adenosquamous carcinoma and pure SCC are compared. However, SCC antigen might be elevated, allowing a serologic monitoring of treatment effectiveness or progression of the disease (6).

Primary SCC of the prostate may spread along the nerves, locally extend to periprostatic tissues, bladder and seminal vesicles, and metastasize to lymph nodes and bone. In contrast to adenocarcinoma, metastatic bone lesions are osteolytic (5). The average estimated survival time for prostatic SCC is not long (6-24 months) (2). There have been several studies reporting multimodal therapy for prostate SCC. Munoz et al. (7) reported a long survival (60 months) with a combination of chemotherapy and radiotherapy. They administered 3 courses of chemotherapy with cisplatin and 5 -fluorouracil followed by radiotherapy, 46 Gy to the pelvis, and 20 Gy to the prostatic area. Uccibayashi and colleagues (8) showed a survival time of 21 months with a combination of radiotherapy and chemotherapy. Their patient received $54 \mathrm{~Gy}$ radiation to the pelvis, and chemotherapy with bleomycin and cisplatin. Majeed et al. (9) reported 18 months of survival with a combination therapy including radical retropubic prostatectomy and bilateral pelvic lymphadenectomy, external beam radiotherapy (2520 cGy) to the prostate bed, and chemotherapy with mitoxantrone and cisplatin. Similarly, Okada and Kamizaki (10) achieved an 18-month survival using a multimodal treatment approach in a patient with lymph node involvement. They treated their patient with $50 \mathrm{~Gy}$ radiation to the pelvis, and a $10 \mathrm{~Gy}$ boost to the prostate, along with chemotherapy with prednisone, etoposide, procarbazine and cisplatin.

\section{Conclusion}

In conclusion, treatment modalities for prostatic SCC are still limited. Comparisons of surgery and radiotherapy, and chemotherapy and hormone therapy showed that they were all ineffective. Combination therapy provides overall survival advantage over monotherapy. However, the origin of prostate SCC has long been a topic for debate, and a better understanding of its biology might help development of effective, novel therapies.

\section{Ethics}

Informed Consent: Consent form was filled out by all participants. Peer-review: Internal peer-reviewed.

\section{Authorship Contributions}

Surgical and Medical Practices: Yasin Aydoğmuş, Demirhan Orsan Demir, Concept: Muhammet Fatih Kılınç, Ömer Gökhan Doluoğlu, Design: Tolga Karakan, Ömer Gökhan Doluoğlu, Data Collection or Processing: Elif Özer, Demirhan Orsan Demir, Analysis or Interpretation: Elif Özer, Tolga Karakan, Literature Search: Yasin Aydoğmuş, Muhammet Fatih Kılınç, Writing: Muhammet Fatih Kılınç. Conflict of Interest: No conflict of interest was declared by the authors.

Financial Disclosure: The authors declared that this study has received no financial support.

\section{References}

1. Epstein Jl, Algaba $F$, Yang $X J$, et al. Tumours of the prostate. In Eble JN, Sauter G, Epstein JI, Sesterhenn IA eds, Tumours of the Urinary System and Male Genital Organs, Chapter 3. Lyon: IARC Pres; 2004. p.160-208.

2. Mazzucchelli R, Lopez-Beltran A, Cheng L, Scarpelli M, Kirkali Z, Montironi R. Rare and unusual histological variants of prostatic carcinoma: clinical significance. BJU Int 2008;102:1369-1374.

3. Moskovitz B, Munichor M, Bolkier M, Livne PM. Squamous cell carcinoma of the prostate. Urol Int 1993;51:181-183.

4. Wang W, Epstein Jl. Small cell carcinoma of the prostate. A morphologic and immunohistochemical study of 95 cases. Am J Surg Pathol Jan 2008;32:65-71.

5. Mott $\sqcup$. Squamous cell carcinoma of the prostate: report of 2 cases and review of the literature. J Urol 1979;121:833-835.

6. Ulloa $S A$, Iturregui JR, Amézquita $M$, Ortiz VN. Squamous cell carcinoma of the prostate: case report and review of literature. Bol Asoc Med P R 1997;89:192-194.

7. Munoz F, Franco P, Ciammella P, Clerico M, Giudici M, Filippi AR, Ricardi U. Squamous cell carcinoma of the prostate: long term survival after combined chemo-radiation. Radiat Oncol 2007;2:15.

8. Uccibayashi T, Hisazumi H, Hasegawa M, Shiba N, Muraishi Y, Tanaka T, Nonomura A. Squamous cell carcinoma of the prostate. Scand J Urol Nephrol 1997;31:223-224.

9. Majeed F, Javed TA, Khan AU, Koerber RK. Primary squamous cell carcinoma of the prostate: a novel chemotherapy regimen. J Urol 2002;168:640.

10. Okada E, Kamizaki H. Primary squamous cell carcinoma of the prostate. Int J Urol 2000;7:347-350. 